\title{
Is It Really a Risk? The Parameters of the Criminalisation of the Sexual Transmission/Exposure to HIV
}

The Journal of Criminal Law

(C) The Author(s) 2020 Article reuse guidelines: sagepub.com/journals-permissions DOI: I0.1 I77/00220I8320908668 journals.sagepub.com/home/cl

(S)SAGE

\section{David Hughes \\ Teesside University, UK}

\begin{abstract}
This article considers whether there is a rationale for criminalisation of the sexual transmission and exposure to HIV by reviewing the harm principle. The article then provides a comparative jurisdictional analysis of transmission and exposure in three particularised jurisdictions: England, Canada and the US. It will be established that few jurisdictions truly consider the risk of serious harm, and thus lack a theoretical foundation for criminalisation. A comparison of relational judicial precepts will follow the discussion of extant law in each country. The final part of the article proposes a bespoke new legislative framework that will criminalise certain types of transmission and exposure.
\end{abstract}

\section{Keywords}

HIV, criminal, exposure, comparative law, England

\section{Introduction}

The contemporary position in the reviewed jurisdictions has shifted to criminalise transmission and exposure to the virus. Prima facie, the criminalisation of transmission and exposure to HIV corresponds to the harm principle, as Feinberg has stated that actual harm, and situations that pose a risk of serious harm are a sound basis for state interference. ${ }^{1}$ The focus of this article is to assess the parameters of such criminalisation, to ensure that only the most culpable acts, which here it is suggested include reckless transmission and intentional exposure, should be criminalised. To achieve this goal, the first part of this piece of work will set out the position of transmission and exposure from a theoretical perspective. This section will present a discussion of the harm principle: this it is argued is the prerequisite for assessing culpability based upon exposure respectively. The harm principle is chosen for the foundation of criminalisation as the significant risk of serious harm is a term that has been used throughout the

1. Joel Feinberg, Harm to Others: the Moral Limits of Criminal Law (OUP, Oxford 1984) 11.

\section{Corresponding author:}

David Hughes, School of Social Sciences Humanities and Law, Teesside University, Middlesbrough TSI 3BX, UK.

E-mail: D.Hughes@tees.ac.uk 
jurisdictions. ${ }^{2}$ This rationalisation provides a sound basis for delineating the parameters of criminalisation and provides an approach that has not been previously explored in this manner within the context of HIV.

The article will then assess the extant position of transmission and exposure by individually evaluating the legislative and judicial precepts within England, Canada and the US. ${ }^{3}$ In England, the current approach is that individuals will be prosecuted for transmitting or exposing another to the virus. ${ }^{4}$ The latter circumstance does not accord to the harm principle. The Canadian jurisdiction allows for criminalisation of transmission and exposure to the virus. There will be criminal sanctions, within Canada, if the defendant's conduct poses a 'significant risk of serious harm' that has a 'realistic possibility of transmission of the virus'. 5 The test promulgated by the Supreme Court appears to accord to the harm principle, however, it will be demonstrated that the judiciary places too much emphasis upon the magnitude of harm without due consideration of the probability of harm, as this approach includes less risky behaviour. The final section of this part will assess the various American legislative methods that criminalise exposure to the virus. It will be argued that the present situation within the number of American jurisdictions is devoid of principle as there is no real consideration of what will equate to a harm under Feinberg's definition of the term.

The penultimate part of this article critically compares the approaches that have been adopted in the aforementioned countries with emphasis placed upon the harm principle. It will be shown that there are similarities and significant differences in the jurisdictional approaches. The final element of this work will propose a new statutory footing that will not only criminalise transmission but also prohibits certain risky activities that expose an individual to the virus. This provides a legislative framework that accords to Feinberg's harm and utilises appropriate elements from the three jurisdictions within this analysis.

\section{The Harm Principle and the Risk of Harm}

The leading proponents of the harm principle have defined harm to facilitate criminalisation when the sanction prevents harm to others. ${ }^{6}$ It is relatively undemanding to construct a case for criminalising conduct when HIV has been transmitted: there is a clear indication of harm. ${ }^{7}$ The harm principle is not restricted to actual harm, as Feinberg submits that the risk of serious harm is also within its ambit. ${ }^{8}$ Exposure to HIV in contrast to transmission is more problematical to reconcile. This is made more onerous a task when sympathy can be attributed to an individual who may be convicted of exposing another to the virus. This empathy can begin to erode when the advertence of the defendant, and the activity that that person has partaken in, is taken into consideration. If the activities of the infected individual are of a high risk 9 to the recipient, then this is a justification for criminalising that conduct. There appears to be no rationale as to why certain types of conduct should evade a criminal sanction. The criminalisation of this type of behaviour is further reinforced by a defendant intending to transmit the virus.

2. For example: $R v$ Cuerrier [1998] 2 SCR 371; Iowa Code $\S 709 \mathrm{D}$ (2018).

3. A comparative analysis is suited for reform proposals. The US was chosen for this purpose as a number of states already have legislation that specifically addresses the criminalisation of HIV. Canada deals with transmission/exposure via the general criminal law, and is suitable for comparison purposes. Thus, the comparison is based upon one jurisdiction that has specific legislation, and the another that has utilised the general criminal law.

4. $R v$ Dica [2004] QB 1257; $R$ v Rowe [2018] EWCA Crim 2688.

5. $R$ v Cuerrier (n 2); $R$ v Mabior 2012 SCC 47.

6. John Stuart Mill, On Liberty (John Gray and GW Smith (eds), Routledge London 1991); Feinberg (n 1).

7. Margo Kaplan, 'Rethinking HIV-Exposure Laws' (2012) 87 Indiana LJ 1517, 1523.

8. Feinberg (n 1) at 11.

9. For types of activity and risk see: Centres for Disease Control $<$ https://www.cdc.gov/hiv/basics/transmission.html $>$ accessed 15 January 2020. 
To enable the criminalisation of the risk of serious harm, Feinberg has specified that it is the risk and severity that is fundamental:

... the greater the probability of harm, the less grave the harm needs to be to justify coercion; the greater the gravity of the envisioned harm, the less probable it need be. ${ }^{10}$

Thus, criminalisation, in Feinberg's view, is dependent upon the seriousness of the harm and the likelihood of the harm occurring. It is the combination of that magnitude and probability that enables a legislator to criminalise certain risks of serious harm, and the combination of the two is known as risk. ${ }^{11}$ In cases concerning HIV exposure, the magnitude of harm is apparent, as an individual who exposes another to the virus can be said to be putting that sexual partner at risk of contracting a life-changing illness. It is evident that because of the seriousness of the illness that low risks of transmission ought to be criminalised. This signifies that, if there is a statistical probability of transmission, then this is a sound basis for criminalising exposure. This is not the end of the matter as a further ingredient is proposed by Feinberg, whereby the social utility of the activity must be considered. ${ }^{12}$ It must be accepted that sexual intercourse is beneficial to individuals and society. ${ }^{13}$ In these circumstances Feinberg suggests that, 'the greater the social utility of the act or activity in question, the greater must be the risk of harm (itself compounded of gravity and probability) for its prohibition to be justified'. ${ }^{14}$ There must be an acceptance of the benefits to society, and that an HIV+ individual cannot be expected to live a life of abstinence from sexual activity.

The risk of infecting another with the virus varies, and depends upon a number of factors including the type of sexual activity, and whether the HIV + positive partner is the insertive or the receptive partner. ${ }^{15}$ This implies that too remote a risk of transmission should not be criminalised as the law should not be concerned with activities that pose a low or negligible risk of transmission. ${ }^{16}$ Others suggest differently and stipulate that by exposing someone to a risk that it can be considered that that individual has harmed that person. ${ }^{17}$ This approach would place too much emphasis on the magnitude of harm, while appearing to deem the probability of harm to be irrelevant. The appropriate method to distinguish between criminal and non-criminal harm, within the context of HIV exposure, is by acknowledging the state of mind of the defendant and the level of risk within an activity. There should be a demarcation line that may exclude certain circumstances and types of conduct, as being considered to be a risk of serious harm. ${ }^{18}$ The rationale being that the likelihood of transmission under these conditions is significantly reduced. ${ }^{19}$ When these parameters are ascertained, it will be possible to construct a legislative framework that will criminalise risky behaviour, and exclude behaviour that can be considered to be a nominal risk. It is only then that the law can be stated to be considered as a just tool for criminalising risky behaviours. The limitations to criminalisation can be determined from the type of sexual activity, viral load and condom use. ${ }^{20}$

10. Feinberg (n 1) at 191.

11. Ibid 188-9.

12. Ibid 191.

13. Hebert Lionel Adolphus Hart, Law, Liberty, and Morality (OUP, Oxford 1963) 22.

14. Feinberg (n 1) at 191

15. Francoise Barre-Sinoussi1, Salim S Abdool Karim, Jan Albert and others, 'Expert Consensus Statement on the Science of HIV in the Context of Criminal Law' (2018) 21(7) JIAS < https://onlinelibrary.wiley.com/doi/epdf/10.1002/jia2.25161> accessed 15 January 2020.

16. Feinberg (n 1) at 189.

17. Claire Finkelstein, 'Is Risk a Harm' (2003) 151 U P L Rev 963, 988.

18. For example unprotected oral intercourse.

19. There have been no reported criminal cases of transmission with low risk activities.

20. Francoise Barre-Sinoussil and others (n 15). 
The harm principle establishes a case for criminalising transmission and lays the foundation for the criminalisation of exposing another to the virus. It has been suggested that any type of exposure, where transmission has not taken place, would offend the complainant but has not harmed them per se. ${ }^{21}$ If an individual is exposed when there is a significant risk, or exposed where there is a negligible risk, it can still equate to the same psychological impact upon an exposed individual. It is the defendant's state of mind that is important, as intentional exposure that causes a significant risk of serious harm that should be subject to prosecution, as exposure that poses a low or negligible risk infers no culpability on the part of the defendant: rather, it can infer that that individual was acting responsibly. ${ }^{22}$ The position of exposure and the transmission of HIV within each of the jurisdictions will now be considered.

\section{The Criminalisation of Sexual Transmission and Exposure to HIV in England}

The current English position is that in most cases, the defendant has recklessly transmitted the virus to an unsuspecting complainant. ${ }^{23}$ Section 20 of the Offences Against the Person Act 1861 does not accommodate a prosecution based upon exposure. The Crown Prosecution Service (CPS) affirms this position by specifying that there can be no prosecution for exposing another to the virus when the defendant has acted recklessly, ${ }^{24}$ but this does not denote that there have been no prosecutions when there has been exposure to the virus. ${ }^{25}$ Prosecutions have been predominantly attributed to transmission of the virus, but there have been prosecutions when the defendant exposed the complainant to HIV. ${ }^{26}$ For a successful conviction, within this circumstance, the defendant must have acted intentionally, and can be seen in $R v$ Rowe $^{27}$ where the defendant deliberately exposed unsuspecting individuals to the virus. ${ }^{28}$ This is in contrast to the Law Commission report that proposes that there should be no criminal offence of exposure to disease. ${ }^{29}$ It is deemed that it 'would be strange and offensive' to criminalise such conduct. The Law Commission does not provide a coherent rationale for such assertions, other than it would be 'unfair and overinclusive'. The leading cases have been where transmission has taken place, and the analysis of England will primarily focus upon cases concerning the transmission of the virus.

\section{English Judicial Precepts and the Sexual Transmission of HIV}

The leading authorities in England have been cases when the virus has been transmitted. In Dica, ${ }^{30}$ the defendant was alleged to have transmitted the virus to two unsuspecting complainants, whereas, in Konzani, ${ }^{31}$ the defendant was believed to have transmitted the virus to three individuals. The basis of the appeal, in both cases, concerned the availability of consent as a defence, and there was no particularised issue raised in relation to transmission of HIV. There were still posited questions as to whether the conduct of the defendant equated to a criminal act. At the time of Dica, the transmission of infectious disease was not considered to be an offence under s 20 of the Offences Against the Person Act

21. Feinberg (n 1) at 45.

22. See: David Hughes, 'Condom Use, Viral Load and Type of Sexual Activity as Defences to the Sexual Transmission of HIV' (2013) 77 JCL 136.

23. $R$ v Dica [2004] EWCA Crim 1103.

24. Crown Prosecution Service (CPS) ‘Intentional or Reckless Sexual Transmission of Infection’ <https://www.cps.gov.uk/legalguidance/intentional-or-reckless-sexual-transmission-infection> accessed 15 January 2020.

25. $R v$ Rowe (n 4).

26. Ibid.

27. [2018] EWCA Crim 2688.

28. Criminal Attempts Act 1981.

29. Law Commission, Reform of the Offences Against the Person, (Law Com No 361, 2015) para 6.145.

30. $R v \operatorname{Dica}(\mathrm{n} 23)$.

31. $R$ v Konzani [2005] EWCA Crim 706; [2005] 2 Cr App R 14. 
$1861 .^{32}$ Judge LJ resolved to remedy this lacuna and held that an offence under that statutory provision could consist of more than actual physical assaults. ${ }^{33}$ The change in position by Judge LJ provided an elaborate discussion that finally overruled Clarence ${ }^{34}$ as the authority that s 20 can only be committed via a physical assault. Judge LJ reaffirmed the endorsement ${ }^{35}$ of Hawkins J minority dictum in Clarence. ${ }^{36}$ In Clarence, ${ }^{37}$ Hawkins J stated that the word 'inflict' was not exclusively attributed to physical assaults. ${ }^{38}$ Judge LJ asserted that:

Whether the consequences suffered by the victim are physical injuries or psychiatric injuries, or a combination of the two, the ingredients of the offence prescribed by s. 20 are identical. If psychiatric injury can be inflicted without direct or indirect violence, or an assault, for the purposes of s.20 physical injury may be similarly inflicted. ${ }^{39}$

His Lordship therefore overruled the precedent from Clarence $^{40}$ and stated that cases where transmission of HIV has transpired will equate to grievous bodily harm. ${ }^{41}$ Cherkassky submits that the court accepted the erosion of Clarence by confirming that there was no longer a distinction to be drawn between immediate and delayed harms. ${ }^{42}$ It is the harm, and not the timing of the harm, that became of paramount importance.

\section{Should S 20 Be the Appropriate Offence for the Transmission of HIV?}

The utilisation of the particular statutory provision in s 20 (infliction of grievous bodily harm) has caused unease. Weait specifies it was not the purpose of the provision to be applied to the transmission of disease. ${ }^{43}$ There is nothing contemporary about the criminalisation of transmission of disease, and the use of the Offences Against the Person Act 1861. In Sinclair, ${ }^{44}$ a case that concerned the transmission of a sexually transmitted disease, the defendant was successfully prosecuted for a non-fatal offence, when he sexually transmitted gonorrhoea to the unsuspecting complainant. ${ }^{45}$ It appears that the criminalisation of the transmission of disease has been accessible to prosecutors since the inception of the 1861 Act, and this may be attributed to the harm that such infections can cause.

It is apparent that criminalisation of the reckless transmission of HIV is firmly entrenched within English criminal law, and that the magnitude of harm is not the primary consideration. ${ }^{46}$ In $\mathrm{Dica},{ }^{47}$ and Konzani, ${ }^{48}$ it was emphasised that the prosecutors were not attempting to prosecute the defendants for intending to transmit the virus, but it follows that if an offence can be committed under s 20 , then a defendant who intends to transmit the virus can also be subject to prosecution under s 18 of the Offences

32. Offences Against the Person Act 1981 s 20 'Whosoever shall unlawfully and maliciously wound or inflict any grievous bodily harm upon any other person, either with or without any weapon or instrument, shall be guilty of a misdemeanour'.

33. $R$ v Dica (n 23).

34. (1888) 22 QBD 23.

35. $R v$ Wilson (Clarence) [1984] AC 242.

36. $R v$ Dica (n 23) [24]-[26].

37. $R v$ Clarence (1888) 22 QBD 23.

38. Ibid 50

39. $R$ v Dica (n 23) [30].

40. $R v$ Clarence (n 37).

41. $R$ v Dica (n 23) [30].

42. Lisa Cherkassky, 'Being Informed: The Complexities of Knowledge, Deception and Consent when Transmitting HIV' (2010) 74 JCL 242, 246.

43. Matthew Weait, 'Criminal Law and the Sexual Transmission of HIV: $R v$ Dica' (2005) 68 MLR 121, 133.

44. $R$ v Sinclair (1867) 13 Cox, C. C. 28.

45. Section 47 Offences Against the Person Act 1861.

46. Weait (n 43) 125.

47. $R v$ Dica (n 23).

48. $R$ v Konzani (n 31); [2005] 2 Cr App R 14 
Against the Person Act 1861. This has been confirmed in CPS guidelines. ${ }^{49}$ Currently, there have been limited prosecutions in England for intentional transmission of the virus, there has been one individual convicted for this type of wrongdoing. In $R v$ Rowe ${ }^{50}$ the defendant was convicted of several offences including intentional transmission of the virus. Rowe's culpable behaviour would also have secured a conviction within the proposed legislative framework that is set out at the end of this article. There was cogent evidence to establish a clear intent to transmit the virus to unsuspecting individuals. Intentional exposure will now be explored.

\section{English Statutes and Intentional Exposure to HIV}

The majority of prosecutions have been through the reckless transmission of the virus. The CPS guidelines and a recent high-profile case confirm that exposing another to the virus may be subject to prosecution under s 1 of the Criminal Attempts Act 1981. This prosecutorial route is for attempting to commit grievous bodily harm with intent. ${ }^{51}$ The position in England, vis-à-vis the attempted infliction of grievous bodily harm, is that the risk of infection is irrelevant. ${ }^{52}$ It would be immaterial that the defendant partook in an activity that posed virtually no risk of transmission. In these circumstances, a defendant would be guilty of an attempt if he intended to transmit the virus to another.

Theoretically, this may denote that an individual who believed that he was infected with the virus, but was in fact HIV negative, would be liable to a criminal sanction if he intended to transmit the virus through intercourse. ${ }^{53}$ This would be what Hogan describes as an 'absolute impossibility'. ${ }^{54}$ No matter how much the defendant tried he would not be able to transmit the virus. The absurdity of the situation in relation to this particular type of conduct is evident and is an affront to rationality. The only exclusion to inculpation based upon the law of attempt is when there an intent to commit an 'imaginary' crime, in other words a crime that does not exist. ${ }^{55}$ It seems; therefore, that it would be immaterial whether the defendant could transmit the virus provided that there was sufficient evidence adduced that demonstrates his actions were more than preparatory, and that he intended to infect another with HIV through sexual intercourse.

\section{The Binary Approach to Criminalisation of HIV in English Law}

It has been demonstrated that the judiciary and prosecutorial authorities in England have endeavoured to address transmission and exposure to the virus. The law seems to be settled in terms of doctrinal principles in relation to the reckless transmission of HIV. This does not indicate that the judicial precepts are correct, as there seems to be no theoretical underpinning to this conclusion. Those who intended to transmit the virus, but are unsuccessful, are subject to sanctions for exposing another to HIV. This position does not take into consideration the risk of serious harm as it is the defendant's mental state that is of paramount importance. ${ }^{56}$ Therefore, the extant law in England that facilitates criminalisation of

49. Crown Prosecution Service (CPS) (n 24).

50. $R v$ Rowe (n 4). Rowe was convicted of five s 18 offences and five attempts of the same offence. In the case Rowe transmitted the virus to five complainants and exposed a further five to the virus by having unprotected anal intercourse. He met most of the individuals on dating sites.

51. Section 18 of the Offences Against the Person Act 1861.

52. Criminal Attempts Act 1981.

53. See Criminal Attempts $1981 \mathrm{~s} 1(2) ; R$ v Shivpuri [1987] AC 1.

54. Brian Hogan, 'Attempting the Impossible' (1986)10 Trent L.J. 1, 4.

55. Glanville Williams, 'Attempting the Impossible-The Last Round?' (1985) NLJ 337, 338. Williams gives the example of the individual who is 'smuggling sugar into the country, believing that this is prohibited, when in fact there is no prohibition on importing sugar'.

56. For a discussion on risk and disclosure see: Samantha Ryan, “'Active Deception” v Non-Disclosure: HIV Transmission, NonFatal Offences And Criminal Responsibility’ (2019) Crim LR 4. 
exposure does not correspond to the harm principle, and this is not how the law should develop. The suggested statutory provision herein will demonstrate that the risk of serious harm must be accounted for within any statute that criminalises exposure to the virus. Further to extirpation of English law substantive principles, the legal kaleidoscope turns to examine Canadian law on the criminalisation of exposure and transmission of HIV that will now be critically evaluated as part of comparative analysis critique.

\section{Canada: Exposing or Transmitting the Virus to an Unsuspecting Sexual Partner}

The Canadian jurisdiction has general criminal laws that enable the prosecution of a defendant who expose or transmits the virus to an unsuspecting complainant. ${ }^{57}$ There have been a significant number of prosecutions within Canada, ${ }^{58}$ and these were subsequent to the leading judgment of $R v$ Cuerrier. ${ }^{59}$ In Cuerrier, it was confirmed that transmission of the virus was not a pre-requisite for the actus reus element of aggravated assault. ${ }^{60}$ It was stipulated that the defendant can be inculpated if he exposed an unsuspecting sexual partner to the virus. ${ }^{61}$

This does not signify that all HIV+ individuals are expected to disclose their sero-status to prospective sexual partners. An expectation of disclosure is subject to a number of factorisations. There will be a requirement of disclosure if the exposure poses a 'significant risk of harm' that has a 'realistic possibility' of the virus being transmitted. ${ }^{62}$ Anything devoid of this threshold will not be considered to pose a sufficient risk to the complainant, and a defendant will not be expected to disclose their HIV status. The current position appears to accord to the harm principle's definition of the risk of serious harm. ${ }^{63}$ The significant risk of serious harm test will now be examined.

\section{The Criminalisation of the Significant Risk of Serious Harm: Endangering Life}

In Cuerrier, ${ }^{64}$ the defendant was convicted of exposing two unsuspecting complainants to the virus. At issue was whether this type of conduct amounted to aggravated assault. An offence under the provision can be committed if the defendant endangers the life of the complainant. ${ }^{65}$ It was held that the defendant will have endangered the life of the complainant if the exposure caused a significant risk of serious harm. ${ }^{66}$ This approach appears to endorse Feinberg's proposal that the risk of serious harm is an action that can be a criminal harm. ${ }^{67}$

The court's interpretation of the offence is not without critics, and Cory J definition of 'endangering life ${ }^{68}$ has been described as unsuitable by Grant, ${ }^{69}$ who submits that endangering life was taken out of context, and 'may be overreaching the appropriate boundaries' of the offence. ${ }^{70}$ It was suggested that

57. Criminal Code, RSC 1985, c C-46, s 265, s 268.

58. Colin Hastings, Cécile Kazatchkine and Eric Mykhalovskiy, 'HIV Criminalization in Canada: Key Trends and Patterns' $<$ http://www.aidslaw.ca/site/hiv-criminalization-in-canada-key-trends-and-patterns/?> accessed 15 January 2020.

59. R. v Cuerrier, [1998] 2 SCR 371.

60. Ibid.

61. Ibid [95].

62. R. v Cuerrier (n 59); $R$ v Mabior [2012] SCC 47.

63. Feinberg (n 1).

64. R. v Cuerrier (n 59).

65. Criminal Code (n 57).

66. Ibid [95].

67. Feinberg (n 1).

68. Criminal Code (n 57).

69. Isabel Grant, 'The Prosecution of Non-disclosure of HIV in Canada: Time to Rethink Cuerrier' (2011) MJLH 7.

70. Ibid $47-8$. 
there was no deliberation of the true construction of the statute, as it was assumed that exposing another to the virus endangered that person's life. ${ }^{71}$ Any endangerment, submits Grant, ought to be direct and immediate, something that the risk of transmission does not achieve. ${ }^{72}$ Cory $\mathrm{J}$ was correct in proposing that exposure to the virus can endanger the life of the complainant because of the "potential lethal consequences of infection'. The risk is no different than the example promulgated by Grant, it is merely luck on the part of the complainant that denotes that there is no infection. ${ }^{73}$ It is accepted that HIV no longer poses the risks to health that it did when the virus came to prominence in the 1980s and should no longer be considered to be a 'death sentence'. ${ }^{74}$ If the virus is left untreated, or the complainant has an adverse reaction to the medication, it would endanger that individual's life. The discrepancies identified by Grant in relation to the interpretation of aggravated assault do not provide a cogent rationale for excluding exposure from the ambit of prosecution. It does, however, identify that a specific piece of legislation addressing HIV exposure is more appropriate.

\section{The Cuerrier Test: Exposure as a Probability Driven Duty}

The assessment of risk that was proposed in Cuerrier has also been criticised for being more inclined towards the probability of harm, as opposed to the magnitude of harm. ${ }^{75}$ This 'probability driven duty' has been deemed to be unique to this type of case, but Flaherty proposes that there was no consideration of the 'magnitude of harm'. ${ }^{76}$ By failing to contemplate the relevance of the magnitude of harm, Flaherty suggests that the social cost of disclosing an HIV status was the prevailing concern. ${ }^{77}$ If there is to be criminalisation of the risk of serious harm then the social utility of the conduct, the probability of transmission and the magnitude of harm, are essential ingredients. ${ }^{78}$ Flaherty's proposal places exclusivity towards the magnitude of harm rather than considering the social utility of sexual intimacy, and the probability of harm, as it was stipulated by Flaherty that if the seriousness of infection were taken into account then disclosure would be expected on all occasions. ${ }^{79}$ This is an inadequate proposal that would not fully assess the risk of serious harm, as both the magnitude and the probability of harm are countervailing measures that are necessary for establishing whether a risk should be considered to be sufficient to be a criminal harm. At some point, the probability of the risk occurring will become so remote that the magnitude of harm will bear no relevance in relation to the risk of serious harm, and the courts endorsed this by proposing that the test for inculpation is when there is a significant risk of serious harm.

\section{Mabior and the Realistic Possibility of Transmission}

The seriousness of the risk of infection has been further considered by the Supreme Court decision of $R v$ Mabior ${ }^{80}$ when they established the realistic possibility of transmission test. ${ }^{81}$ This further endorsed an assessment of the relationship of the risk of transmission, and the seriousness of infection. The court appeared to recognise that there must be a balance between the magnitude of harm, and the probability of

71. Ibid.

72. Ibid.

73. Grant (n 69) at 47-8 Grant suggests that if a person is pushed into oncoming traffic but miraculously escapes harm, the endangerment of life is direct and immediate.

74. Erin Dej and Jennifer M. Kilty "“Criminalization Creep”: A Brief Discussion of the Criminalization of HIV/AIDS Nondisclosure in Canada' (2012) 27 Canadian JL Soc 55, 60.

75. John Flaherty, 'Clarifying the Duty to Warn in HIV Transference Cases' (2008) 54 Crim LQ 60, 61.

76. Ibid 61.

77. Ibid 62.

78. Feinberg (n 1) at 191

79. Flaherty (n 75) at 62.

80. $R$ v Mabior (n 62) [18].

81. Ibid. 
harm as a test set to this standard can be justified under the harm principle. It seems that the courts have incorrectly utilised the test to encompass activities that pose a low, or no risk of infection, such as condom use, or an undetectable viral load. ${ }^{82}$ Enabling exposure to be criminalised in this manner is overly complicated and runs counter to public health initiatives. As Feinberg states, the assessment of risk is not a simple task. ${ }^{83}$ There are several factors that need to be measured to be able to ascertain whether there was a significant risk of serious harm that posed a realistic possibility of transmission. The number of appeals following the decision in Mabior emphasise that there is no appropriate demarcation line as to the requisite threshold within Canada. It also demonstrates that the use of the general criminal law may be inadequate in cases of HIV transmission or exposure. ${ }^{84}$

\section{Inculpation Based Upon Attempting to Transmit the Virus: R v Williams}

If all of the constructional elements of aggravated assault cannot be established, then the Supreme Court are satisfied that defendants can be convicted of attempting to commit the offence. In $R v$ Williams, ${ }^{85}$ the defendant had transmitted the virus to the complainant. At issue was whether the full offence of aggravated assault had been committed as there was no consensus of when the complainant acquired the virus. The Supreme Court held that the full offence was not proved, as the complainant may have acquired the virus before the defendant was aware of his sero-status. ${ }^{86}$ It was stated by Binnie $\mathrm{J}$ that there was nothing in the facts of the case that would enable the Court to conclude otherwise. ${ }^{87}$ An attempt requires intent, ${ }^{88}$ and the Canadian Courts have confirmed that the inchoate offence can be committed when there is an impossible attempt providing that it was the defendant's intention to commit the offence. ${ }^{89}$ Williams may have been a case of impossible attempt, as the defendant may have been having unprotected intercourse with an already infected complainant.

\section{Exposure or Transmission: What Should Be the Requirement in Canada?}

Grant $^{90}$ proposes that convictions for serious offences should entail actual transmission, and that this would remove the intricacies that are involved in ascertaining what would constitute a significant risk of serious harm. ${ }^{91}$ It was stated that exposure, where there was a negligible risk of serious harm, would equate to the same mental harm as exposure when there was a significant risk of serious harm, ${ }^{92}$ and there should be a 'stronger nexus between the non-disclosure and the endangerment'. ${ }^{93}$ Contrastingly, there are proponents who suggest that to exclude exposure would be inappropriate, as an individual who recklessly and persistently has unprotected intercourse may avoid liability. ${ }^{94}$ Persistent conduct, it may

82. Cecilé Kazatchkine and others, 'HIV Non-disclosure and the Criminal Law: An Analysis of Two Recent Decisions of the Supreme Court of Canada' (2013) 60 Crim LQ 30, 37.

83. Feinberg (n 1).

84. For example, see: $R . v C B, 2017$ ONCJ 545; $R v$ WH, 2015 ONSC 6121; $R v$ Thompson, 2018 NSCA 13.

85. $R v$ Williams [2003] 2 SCR 134.

86. Ibid [14].

87. Ibid [57].

88. Criminal Code, RSC 1985, c C-46, s 24: 'Every one who, having an intent to commit an offence, does or omits to do anything for the purpose of carrying out the intention is guilty of an attempt to commit the offence whether or not it was possible under the circumstances to commit the offence...'.

89. United States of America v Dynar [1997] 2 SCR 462, 1997 CanLII 359 (SCC) [59].

90. Grant (n 69) at 56.

91. Ibid.

92. Ibid.

93. Isabel Grant, ' $R v$ Mabior and $R v D C$ : Sex, Lies, and HIV: The Over-Criminalization of Persons with HIV' (2013) 63 UTLJ 475.

94. Matthew Cornett, 'Criminalization of the Intended Transmission or Knowing Non-disclosure of HIV in Canada' (2011) 5 MJLH 61, 89-90. 
be argued, could denote intentional behaviour and may justify criminalisation of intentional exposure. Criminalising exposure ought to encompass those who intend to transmit the virus by partaking in acts of unprotected intercourse. This would accord to Feinberg's harm principle, and correspond to public health and policy contemplations, and may eventually facilitate the reduction of infections.

The jurisprudence of Canada, in relation to exposure, prima facie corresponds to Feinberg's definition of risk of serious harm. The test that has been set out in Cuerrier and Mabior ${ }^{95}$ could align to the magnitude of harm and the probability of harm. It appears that the court place more emphasis on the magnitude of harm. It may be more perceptive to criminalise actual transmission, and the intentional exposure of the virus when there is a risk of serious harm. The suggested statutory provision in this article emulates such a proposal. The American position will now be evaluated, to provide comparative extirpation of the transmission/exposure dichotomy.

\section{The US State Laws Divergent Approaches to Criminalising Sexual Exposure to HIV}

In 1988, the Presidential Commission stipulated that any specific legislation should criminalise behaviours that are likely to transmit the virus. ${ }^{96}$ It was stated that, 'HIV-infected individuals who knowingly conduct themselves in ways that pose a significant risk of transmission to others must be held accountable, for their actions' ${ }^{97}$ The Presidential Commission also proposed that the criminalisation of exposure to the virus ought to be based upon scientifically accepted routes of transmission. ${ }^{98}$ It is at once noticeable that the suggestions correspond to Feinberg's classification of a risk of serious harm thereby facilitating a justification for criminalising exposure to the virus. The Model Penal Code (MPC) also addresses risky behaviour but does not have an expressly stated provision in relation to transmission or exposing an unsuspecting individual to HIV. ${ }^{99}$ The lack of a legislative framework on HIV within the MPC does not denote that exposure has been excluded from criminalisation. All of the specific pieces of HIV legislation within the various States allow for the criminalisation of exposure. ${ }^{100}$ Actual transmission, although criminalised within a number of the jurisdictions, is not the principal consideration.

There are a significant number of HIV specific laws that detract from defining the parameters of the conduct that is prohibited. These states did not demonstrate any uniformity, as terms such as 'could result in transmission', 'sexual conduct' and 'expose'101 have been employed by the state legislators to describe the prohibited activities. These definitions have the potential to incorporate all manner of harm, even if the conduct poses a negligible risk of harm occurring. For example, in a literal sense any type of activity would 'expose' another to the virus. The following exposition will focus upon HIV specific criminal provisions that can be separated into four distinct groups. There are statutes that specify exposure as the sufficient level of culpability; those that criminalise sexual contact; provisions that criminalise the risk of harm or words to that effect, and a provision that precludes intentional exposure through unprotected intercourse. These states are selected on account of the various mechanisms that are utilised to criminalise exposure, in that certain states have not accounted for the risk of harm, while

\footnotetext{
95. Significant risk of harm that has a realistic possibility of transmitting the virus being transmitted.

96. The Presidential Commission on the Human Immunodeficiency Virus Epidemic Report (1988).

97. Ibid 130.

98. Ibid.

99. Model Penal Code $\S 211.2$ (1985).

100. HIV Criminalization in the United States: A Sourcebook on State and Federal HIV Criminal Law and Practice Third Edition $2019<$ https://www.hivlawandpolicy.org/sites/default/files/HIV\%20Criminalization\%20in\%20the\%20U. S. $\% 20$ A $\% 20$ Sourcebook\%20on\%20State $\% 20$ Fed\%20HIV\%20Criminal\%20Law\%20and\%20Practice\%20062519.pdf> accessed 15 January 2020.

101. For example: Wash Rev Code $\S 9 A .36 .011$ (2018); Iowa Code $\S 709$ C.1(2)(b) (2011) (repealed); La Rev Stat Ann $\S 14: 43.5$ (2018).
} 
others have criminalised conduct that poses a significant risk of harm. It is appropriate to firstly examine the criminalisation of exposure.

\section{Exposure and the Interpretation of Washington's Statute}

The Washington statute specifies that a defendant will be guilty of the offence if he intentionally: 'administers, exposes, or transmits to or causes to be taken by another, poison, the human immunodeficiency virus ... $\cdot{ }^{102}$ It is obvious that that particular section of the provision provides no definition of 'exposes', and this is evident throughout the rest of particularised statute. MacArthur proposes that the rationale for a specific law that criminalises 'exposure', rather than specifying the prohibited conduct, is that the statute avoids any accusations of being overbroad. ${ }^{103}$ However, the breadth of the provision is apparent; it may encompass activities that pose a negligible risk or no risk of transmission. ${ }^{104}$ Any activity that would expose another to the virus, regardless of the risk of transmission, could be within the ambit of the statute. If it is accepted that the provision is not overbroad then it is still possible that the statute is 'vague', as there is no specifics of what will equate to exposure. The appellate Court of Washington has provided limited guidance as to what can be considered to be exposure.

Washington's Court of Appeal has defined the parameters of exposure to encompass 'other activities'. ${ }^{105}$ In State $v$ Whitfield, ${ }^{106}$ the defendant had been charged with assault in the first degree by exposing or transmitting the virus to seventeen women. Five of the women had tested positive for the

102. Wash Rev Code $\S 9$ A.36.011(1)(b) (2018): at the time of writing (15 January 2020) there is a Bill going through the Legislature whereby HIV will be removed from this offence, and new legislative framework will be added to chapter 70.24 RCW that will provide a bespoke offence:

new section is added to chapter $70.24 \mathrm{RCW}$ to read as follows:

1. It is unlawful for a person who knows that he or she has HIV to have sexual intercourse if:

a. The person has been counseled by a health care provider or public health professional regarding the risk of transmitting HIV to others;

b. The partner or partners exposed to HIV through sexual intercourse did not know that the person had HIV; and

c. The person intended to transmit HIV to the partner.

2. It is a defense to a prosecution under this section if:

a. HIV was not transmitted to the partner; or

b. (b) The person took or attempted to take practical means to prevent transmission of HIV.

3. a. Except as provided in (b) of this subsection, violation of this section is a misdemeanor punishable as provided in RCW 9A.20.021.

b. Violation of this section is a gross misdemeanor punishable as provided in RCW 9A.20.021 if the person knowingly misrepresented his or her infection status to the partner.

c. Violation of this section does not require registration under RCW 9A.44.130.

4. For purposes of this section, the following terms have the following meanings:

a. 'Practical means to prevent transmission' means good faith employment of an activity, behavior, method, or device that is scientifically demonstrated to measurably reduce the risk of transmitting a sexually transmitted disease, including but not limited to: The use of a condom, barrier protection, or other prophylactic device; or good faith participation in a treatment regimen prescribed by a health care provider or public health professional.

b. 'Sexual intercourse' has its ordinary meaning and occurs upon any penetration, however slight, of the vagina or anus of one person by the sexual organs of another whether such persons are of the same or another sex.

103. Amy McGuire, 'Aids as a Weapon: Criminal Prosecution of HIV Exposure' (1999) 36 Houston L Rev $1787,1811$.

'Constitutional challenges to HIV-specific statutes have generally focused on the statutes' lack of specificity with respect to prohibited conduct. A statute will likely be deemed overbroad if it could interfere with constitutionally protected behavior'.

104. Centres for Disease Control (n 9)

105. State v Whitfield 134 P.3d 1203 (2006).

106. Ibid; 132 Wash App 878 [46]. 
virus. One of the grounds of appeal was the lack of evidence in relation to the 12 women who were HIV negative. Houghton J disregarded this contention by affirming that either actual transmission or exposure was sufficient for the charge to be satisfied. ${ }^{107}$ The Court also appeared to acknowledge that oral, anal or vaginal intercourse could establish that the defendant exposed the complainants to the virus. ${ }^{108}$ Waldman, when discussing Whitfield and factors that may have been relevant to the risk of the virus being transmitted, proposes that the wording of the statute denotes that any sexual contact is considered exposure. ${ }^{109}$ The decision to include anal, oral and vaginal intercourse seems to concur with the accuracy of Waldman's suggestions. However, dicta from Whitfield inferred that some activities may not be considered to be exposure. ${ }^{110}$ It was implied by Houghton $\mathrm{J}$ that protected intercourse would not be considered as exposure. ${ }^{11}$ The allowance of protected intercourse may be seen as an attempt to balance the magnitude of harm and the probability of risk.

Criminalising exposure through oral intercourse can be seen to be contrary to the parameters set out by Feinberg's harm principle, as the social utility of sexual interaction, and the probability and magnitude of harm should be counterbalanced when assessing the risk of serious harm. What is evident is that describing the prohibited activity as 'expose' or 'exposure' does not accord precision or certainty, rather it convolutes the issue. The deficiencies of the provisions that require exposure provide a cogent rationale for an enactment that meticulously defines a risk of serious harm, and this refinement is currently proposed by the Legislature. ${ }^{12}$ Other provisions have also failed to define exposure. One of these being where the prohibited conduct has been expressed in terms such as 'could result in transmission'. 113

\section{American Provisions that Criminalise the Risk of the Virus Being Transmitted}

Initially, the legislators and the appellate court of Iowa declined to acknowledge the relevance of risk by criminalising oral intercourse. ${ }^{114}$ The Supreme Court of Iowa has since recognised that oral or protected anal intercourse may not pose a risk. ${ }^{115}$ This was established in State $v$ Rhoades, ${ }^{16}$ a case concerning a defendant who had an undetectable viral load who exposed another to the virus through unprotected oral and protected anal intercourse. The defendant pleaded guilty, but appealed on the basis of his trial counsel being ineffective by allowing him to plead guilty. ${ }^{117}$

At that time Iowa's statute stipulated that the defendant must not engage in intimate contact that 'could result in transmission'. ${ }^{118}$ The term 'could' had been further defined to mean 'possible'. ${ }^{119}$ It was stated in Rhoades that the term possible may encompass situations that had a remote chance of the virus being transmitted, therefore, the definition necessitated the 'reality of a thing occurring, rather than a theoretical chance', and the judiciary preferred the narrower approach to the term. ${ }^{120}$ It was held that the

107. Ibid [47].

108. Ibid.

109. Ari Ezra Waldman, 'Exceptions: The Criminal Law's Illogical Approach to HIV-Related Aggravated Assaults' (2011) 18 Va. J. Soc. Pol'y \& L. 550, 584.

110. State $v$ Whitfield (n 105); 132 Wash App 878 [47].

111. Ibid [47].

112. See (n 102). At the time of writing (15 January 2020), there is a Bill going through the Legislature whereby HIV will be removed from this offence, and new legislative framework will be added to chapter $70.24 \mathrm{RCW}$ that will provide a bespoke offence.

113. Iowa Code (n 101). This is just for illustrative purposes this is no longer the statutory provision in Iowa.

114. State v Stevens, 719 N.W.2d 547 (Iowa 2006).

115. State v Rhoades 848 N.W.2d 22 (Iowa 2014) 27-8.

116. Ibid.

117. Rhoades was subsequently sentenced to a suspended twenty-five year sentence and placed on probation for five years.

118. Iowa Code $\S 709$ C.1 (2011) (repealed).

119. State v Keene, 629 N.W.2d 360(Iowa 2001) at 365 Cady J acknowledged that court in the earlier decision of State v Keene defined the term 'could' to mean 'possible'.

120. State $v$ Rhoades (n 15). 
court were not prepared to take judicial notice that unprotect oral and protected intercourse could transmit the virus regardless of the level of the defendants viral load. ${ }^{121}$ The court found that there had not been a sufficient factual basis for the district court to accept the plea, and thus the trail counsel had been ineffective.

The outcome of this case indicates that this is a state where the judiciary are recognising that a statutory provision necessitates an appropriate evaluation of the harm principle. The initial prosecution failed to take into account medical advancements, and Cox commends the court for being the first to recognise scientific data. ${ }^{122}$ This is clear when Wiggins $\mathrm{J}$ accepted that medical advancements had reduced the risk of the virus being transmitted. The case is in contrast to cases prior to Rhoades as these encompassed any risk as criminal. This signifies a significant development and could be a precedent that other states may wish to follow and the catalyst for reform. ${ }^{123}$ Frost suggests that it was inappropriate to criminalise Rhoades' conduct as he was unable to transmit the virus, and thus the law did not fulfil its purpose. ${ }^{124}$ This is something that the court and legislator has since recognised.

The 2014 Iowa statute has replaced the more 'draconian' statute and the new statutory provision is more realistic in its approach to exposure. ${ }^{125}$ it is considered to be one of the most enlightened statutory provisions. ${ }^{126}$ The legislators have accepted the limitation of transmitting the virus by utilising this new statutory framework. Exposure that is criminalised must be considered a 'significant risk of harm'. It appears that the 2014 statute provides an appropriate balance between the social utility of sexual interaction, the probability of harm and the magnitude of harm. ${ }^{127}$ Defences such as condom use and viral load are also defined in the legislation. It is suggested that these terms eradicate the criminalisation of theoretical risks. ${ }^{128}$ This is evident as a more realistic approach to the risk of transmission is adopted.

\section{Tennessee State Law: The Significant Risk of Transmission that Must Not Be a Faint, Speculative Risk}

The same can, in part, be said of Tennessee, it seems that the legislator endeavoured to restrict the parameters of 'intimate contact' to those acts that had a high probability of the virus being transmitted, thereby aligning the provision to the harm principle, and the suggestions of the Commission. ${ }^{129}$ This leads to the presumption that only the most high risk activities should be criminalised. ${ }^{130}$

121. Ibid 32

122. Brian Cox, 'Turning the Tide: The Future of HIV Criminalization after Rhoades v. State and Legislative Reform in Iowa' (2016) 11 Nw.J. L. \& Soc. Pol'y 28 at 29

123. Ibid 30.

124. Stephen Frost, 'HIV Criminalization Laws: A Poor Public Policy Choice in the New Era of PrEP' (2016) 6 Wake Forest J.L. \& Pol'y 319 at 328 .

125. Cox (n 122) at 28.

126. Ibid 29.

127. Iowa Code $\S 709 D .2(2018)$ : Definitions: 3 :

'Practical means to prevent transmission' means substantial good faith compliance with a treatment regimen prescribed by the person's health care provider, if applicable, and with behavioral recommendations of the person's health care provider or public health officials, which may include but are not limited to the use of a medically indicated respiratory mask or a prophylactic device, to measurably limit the risk of transmission of the contagious or infectious disease.

128. Cox (n 122) at 44.

129. TENN. CODE ANN. $§ 39-13-109$ (a)(1) (2016): At the time of writing (15 January 2020) there is a Bill going through General Assembly of the State of Tennessee that will amend this legislation. The Bill will further define substantial risk of transmission: 39-13-109 (d)(3) 'Substantial risk of transmission' means a reasonable likelihood of disease transmission to another person as proven by competent medical or scientific evidence. Conduct that competent medical or scientific evidence has proven to pose a low or negligible risk of transmission is not conduct posing a substantial risk of transmission.

130. Leslie E Wolf and Richard Vezina, 'Crime And Punishment: Is There a Role for Criminal Law in HIV Prevention Policy?' (2004) 25 Whittier L. Rev. 821, 879. 
The Supreme Court of Tennessee has re-visited the 'significant risk of harm' test. In State v Hogg, ${ }^{131}$ the defendant had been convicted of exposing a minor to the virus by participating in a number of sexual activities. Hogg appealed to the Supreme Court on the premise that the activities did not pose a significant risk of harm. The appeal was partly allowed, and the court provided some much needed clarification of what would equate to the significant risk of harm. Sharon J stated that a "significant risk" requires a chance of $H I V$ transmission that is more definite than a faint, speculative risk, as shown by expert medical proof ${ }^{132}$ It is apparent that the court attempted to set out the parameters of the requirement by accepting the relevance of balancing the probability of harm and magnitude of harm, but this did not fully transpire. The court may well have been restricted by the definitional elements of the statutory provision, and still proceeded to uphold a conviction where the risk of transmission was significant reduced. ${ }^{133}$ This indicates that the statutory provision needs reform, and a Bill is currently going through the Legislature hat achieves this reform.

The lack of uniformity that has existed in Iowa's and Tennessee's statutes demonstrate that a statutory provision better corresponds to the harm principle by expressly stating what type of conduct is to be prohibited. The divergent approaches can also be observed in jurisdictions that criminalise exposure through sexual contact. This will now be examined in more detail.

\section{US State Provisions that Criminalise Exposure Through 'Sexual Contact'}

If the provision does not stipulate what should equate to sexual contact then it is not easily identified. ${ }^{134}$ In State $v$ Gamberella, ${ }^{135}$ a case heard in the Court of Appeal in Louisiana, the appellant questioned the validity of 'sexual contact'. It was contended that the term may include a number of sexual acts that posed no risk of infection. The appellant was undoubtedly relying upon the probability of harm as the crux of his appeal. This contention was emphatically rejected by Fogg J who stated:

While it is possible this terminology includes sexual acts which are not capable of transmitting the virus, the phrase 'sexual contact' unambiguously describes the unlawful conduct with sufficient particularity and clarity that ordinary persons of reasonable intelligence are capable of discerning the statute's meaning. ${ }^{136}$

What is apparent from the dicta is that the court was reluctant to define the parameters of 'exposure through sexual contact'. There is also circularity to the dicta, as Fogg J stipulates that contact that is incapable of transmitting the virus could be included, and then specifies that there is also a presumption that people of average intellect would be aware of what type of sexual contact would be criminalised. The court afforded no enlightenment of the term, other than inferring that the provision applied to all types of sexual acts irrespective of the risk of the virus being transmitted.

The probability of the risk appears to be considered irrelevant and this is an affront to the risk of serious harm. ${ }^{137}$ It is that, generally, the 'law makers appear to have difficulty incorporating notions of risk'. ${ }^{138}$ There are advantages to providing definitions of the 'prohibited conduct' as this would denote what type of activity is criminalised. ${ }^{139}$ By failing to distinguish between the levels of risks the

131. State v Hogg 448 S.W.3d 877; 2014 Tenn. LEXIS 668.

132. Ibid 888-9.

133. The defendant's convictions for committing the act of fellatio and masturbating the minor were quashed. A conviction for exposure when the minor committed the act of fellatio on the defendant was upheld.

134. La Rev Stat Ann $\S 14: 43.5$ (2018).

135. State v Gamberella, 633 So.2d 595 (La Ct App 1993).

136. Ibid 603 .

137. Carol L Galletly and Steven D. Pinkerton, 'Toward Rational Criminal HIV Exposure Laws' (2004) 32 J.L. Med. \& Ethics $327,329$.

138. Ibid 331

139. James B McArthur, 'As the Tide Turns: The Changing HIV/AIDS Epidemic and the Criminalization of HIV Exposure' (2009) 94 Cornell LR 707, 718. 
legislators are not providing individuals with any incentive to act more responsibly. ${ }^{140}$ A statute ought to set out the parameters of criminal activity so there can be no uncertainty of what will be considered culpable behaviour. This should, and must also, correspond with the probability of the risk occurring. ${ }^{141}$ To correspond with the probability of harm the provision must consider contemporary scientific data and public health initiatives. An individual would then be able to participate in low risk activities without fear of prosecution. Therefore, culpability should only be based upon activities that 'reach a certain threshold'. ${ }^{142}$ A statutory provision should provide this precision, but the current position entails that any intimacy with an HIV positive individual is 'unclean', and there is no consideration of the risks. ${ }^{143}$ The Californian statute provides 'significant risk of harm' test and a list of prohibited activities and this will now be examined.

\section{The Californian Statute: Criminalisation Restricted Unprotected Intercourse and High Risk Activities}

The benefits of defining the prohibited conduct could be seen in the now repealed Californian statutory provision. The Californian provision needs to be considered at this juncture as it criminalises exposure when there is was a 'high risk' of the virus being transmitted. That provision proposed that exposing an unsuspecting complainant to the virus through unprotected sexual activity may lead to a successful prosecution. ${ }^{144}$ Sexual activity was further defined to be unprotected anal or vaginal intercourse; clearly the conduct that was prohibited posed a significant risk of harm. Prosecutions under that provision would only transpire if the exposure by the defendant was intentional. ${ }^{145}$ The restriction of prosecutions to unprotected activity may be seen to strike the appropriate balance between social utility, the probable risk of serious harm and the magnitude of harm. None appear to operate in a supererogatory manner as the statutory definition affords an effective acknowledgement of these factors; this is necessary to accord to the aforementioned harm principle. Wolfe and Vincena are strong proponents of this legislation, contending that it has struck the 'correct balance'. 146

Advocates of the old Californian statutory perspective suggested that the statute is the 'model' code to follow because of the precision in the drafting. ${ }^{147}$ This is evident in the now repealed Californian statute as it is specific in restricting the types of exposure that are criminalised. It is apparent that the legislators had attempted to balance the risk of harm and the magnitude of harm, and only prohibited conduct that poses a significant risk of harm is criminalised. ${ }^{148}$ It is for this reason that Klemm opines that the provision is 'instructive' for other state legislators. ${ }^{149}$ In contradiction, some academicians have propounded that the Californian statutory provision was 'under inclusive' by excluding oral intercourse from the prohibited conduct. ${ }^{150}$ It is conceded that oral intercourse may pose a risk of transmission, but

140. Sarah J Newman, 'Prevention, not Prejudice: The Role of Federal Guidelines in HIV-Criminalization Reform' (2013) 107 NULR 1403, 1419.

141. Mona Markus, 'A Treatment for the Disease: Criminal HIV Transmission/Exposure Laws' (1999) 23 Nova LR 847, 867-9.

142. Kaplan (n 7) at 1540.

143. Ibid 1539.

144. Cal. Health \& Safety Code $\S 120291$ (2017) (repealed).

145. Ibid.

146. Wolf and Vezina (n 130) at 879

147. Jaclyn Schmitt Hermes, 'The Criminal Transmission of HIV: A Proposal to Eliminate Iowa's Statute' (2002) J. Gender Race \& Just. 473, 479.

148. Sara Klemm, 'Keeping Prevention in the Crosshairs: A Better HIV Exposure Law for Maryland' (2010) 13 J. Health Care L. \& Pol'y 495, 523.

149. Ibid 523.

150. Christina M Shriver, 'State Approaches to Criminalizing the Exposure of HIV: Problems in Statutory Construction, Constitutionality and Implications’ (2001) 21 NIU L Rev 319, 328. 
various studies state that that risk is more remote than unprotected intercourse. ${ }^{151}$ The social utility of sexual intercourse denotes that not all risks of transmission should be criminalised, ${ }^{152}$ and it would also be 'unreasonable to prohibit all activity'. ${ }^{153}$

The new Californian statutory provision provides further refinement and proposes that exposure transpires if the defendant engages in conduct that poses a substantial risk of transmission. ${ }^{154}$ What equates to a substantial risk of transmission is further defined to exclude low or negligible risks. ${ }^{155}$ Practical means to prevent transmission act as a defence and include condom use and anti-retroviral medication. This provision recognises scientific advancements, and incorporates essential element that reduce the risk, while the old provision did not acknowledge this defence. ${ }^{156}$ It can be stated that this is a further refinement to an already robust statute.

\section{The US and a Preference Towards the Magnitude of Harm}

It is evident from the aforementioned exposition of the various approaches that exposure will suffice for prosecutions. Proponents of criminalisation tend to place emphasis on exposure as the requisite level for inculpation as this avoids the inherent difficulties in utilising the general criminal law. ${ }^{157}$ Various States have enacted legislation that is more accessible to prosecutors by criminalising conduct that exposes another to the virus. Some legislators have not considered the probability of harm, and the statutory provisions are an affront to the harm principle. While it is conceded that HIV can be a life debilitating virus, and therefore the magnitude of harm is particularly relevant, it must be offset by the social utility of sexual interaction and the probability of harm.

This position can be surveyed in Iowa and California where there is an adherence to the risk of serious harm. It is California that provides the most lucid statute in relation to exposure, as prosecutions only ensue when there has been significant risk of harm. The review of the extant law across the comparator legal systems has revealed significant divergencies in perspective vis-à-vis the conduct threshold of transmission/exposure within particularised offences. It is now appropriate to further compare the respective legal systems juxtapositions with a view to providing overarching reform suggestions via a new statutory pathway.

\section{A Recognition of the Harm Principle or an Acceptance of the Magnitude of Harm: A Comparison of the Legal Systems}

The preceding discussion demonstrates that each of the jurisdictions can accommodate criminalisation of exposure and transmission of HIV. This does not connote that the approaches within each jurisdiction are analogous. There is significant diversity as to how these issues are addressed. A comparative examination of a number of US States and consideration of the Canadian criminal justice system reveals a significant number of prosecutions for both categorisation of harm; whereas, the extant English law is primarily focused upon prosecutions for transmitting the virus.

151. For example see: Ronald H Gray and Maria J Wawer, 'Probability of Heterosexual HIV-1 Transmission per Coital Act in Sub-Saharan Africa' (2012) 205 J Infect Dis 351.

152. Hart (n 13) at 22.

153. Jagoda Jedrychowski, 'Criminalization of HIV-Transmission: Perpetuating Problems Surrounding the Epidemic' (2007) 11 Holy Cross J.L. \& Pub. Pol'y 29, 40.

154. Cal. Health \& Safety Code $\S 120290$ (2018).

155. Ibid.

156. Cal. Health \& Safety Code (n 144).

157. Donald HJ Herman, 'Criminalizing Conduct Related to HIV Transmission (190) 9 St. Louis U. Pub. L. Rev. $351,371$. 


\section{An acceptance of the Criminalisation of HIV Transmission Within All of the Countries}

The findings have established that England is unique; the jurisdiction has mainly prosecuted individuals who have transmitted the virus to unsuspecting complainants. The criminalisation of this type of conduct evidently accords to the harm principle, as transmitting the virus to an unsuspecting complainant can be considered to be a serious harm. ${ }^{158}$

Any concerns in relation to transmission have not been fully addressed in Canada, except for Grant suggesting that criminalisation should only ensue if the virus has been transmitted. ${ }^{159}$ It was proposed that this would avoid the judiciary having to elucidate upon the test set out in Cuerrier. ${ }^{160}$ To exclude criminalisation of exposure, would remove any consideration of the risk of serious harm. There seems to be no rationale for restricting the criminalisation to the actual transmission of the virus, as exposure can fulfil the requirement of the harm principle. ${ }^{161}$ In the US, the primary consideration has been upon enactments defining exposure, rather than issues concerning transmission. This will now be analysed in the context of exposure standardisations and contemporary doctrinal principles.

\section{A Spectrum of Approaches to Exposure to HIV Within the Criminal Justice System}

It is exposure that causes significant disparity between the jurisdictions. The diversity is easily identified, and jurisdictions have criminalised activity that is devoid of the harm principle, while other administrations accede to the parameters of Feinberg's proposal on the risk of serious harm. ${ }^{162}$

Canada, Tennessee, Iowa and California appear to have criminalised conduct that can pose a significant risk of the virus being transmitted. In Canada, the test to ascertain whether a defendant has exposed another to the virus originated in Cuerrier, ${ }^{163}$ where Cory $\mathrm{J}$ stated that activity that poses a significant risk of harm will be considered to be exposing another to the virus. The Canadian legal system had seen a plethora of appeals requesting a significant risk of serious harm standardisation, until the Supreme Court reaffirmed Cuerrier, and further qualified the test to include where there is a realistic possibility of transmission. ${ }^{164}$ This proposed test, if used appropriately, would invariably attain to Feinberg's definition of the risk of serious harm. The test is not sufficiently robust as the ambit of exposure has encompassed conduct that has a low risk of transmission. It is apparent that the extant Canadian law has struggled to provide comity between the harm principle, and the tests set out in Cuerrier and Mabior.

In the US, Iowa's recent statutory response conforms to the harm principle, as exposure is criminalised when the contact could result in a significant risk of the virus being transmitted. ${ }^{165}$ Initially, the legislators and the appellate court in Iowa declined to acknowledge the relevance of risk by criminalising oral intercourse. ${ }^{166}$ The judiciary then began to recognise that certain activities may be precluded, and this approach now accords to the harm principle and the current statute reinforces this. ${ }^{167}$ Kaplan has suggested that any statutory provision should expressly state that exposure to HIV will be considered to be criminal conduct if that activity poses a 'substantial and unjustifiable risk'. ${ }^{168}$ The above extrapolation of Canada and Iowa's original approach only serves to demonstrate the inherent difficulty of utilising tests to that effect. These difficulties can also be seen within the judicial precepts that have

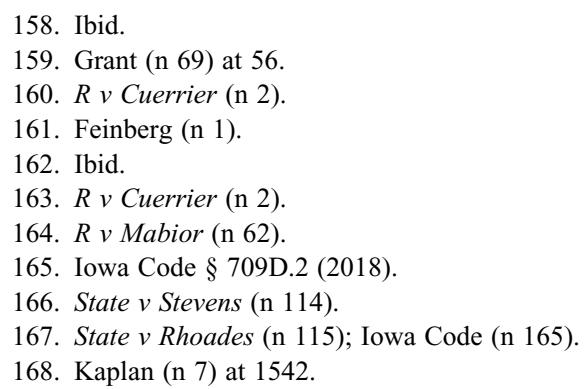


emanated from Tennessee. The Supreme Court in Tennessee accepted that the magnitude of harm and the probability of harm must be balanced, but declined to provide any specific guidance. ${ }^{169}$ It is clear that any provision necessitates precision on what is considered to be a prohibited activity.

California provides that precision by proselytising that only high risk sexual activities are criminalised. ${ }^{170}$ There are distinct advantages to be derived from the statute as it is evident that the legislators proceeded with an enactment that balanced the probability of harm and the magnitude of harm. If the risk of serious harm is to be a recognised as a rationale for criminalisation then the primary focus should not be based upon the magnitude of harm.

Other American jurisdictions appear to be on a 'frolic of their own', by failing to determine any definition of exposure or sexual conduct. ${ }^{171}$ The States that have criminalised exposure and sexual conduct are deficient as the parameters of what is believed to be restricted activities are not defined. These States have criminalised activity that poses a low risk of infection. There has been no consideration of the type of action that should amount to exposing another to the virus. There has been no acceptance of or an alignment to the risk of harm. It is left to the judiciary to ascertain the parameters of prohibited conduct. In the Appeals Court of Washington, the Court extended the stricture of exposure to encompass activities that pose a low risk of transmission. The issues surrounding the terminology that has been utilised in these provisions demonstrate that a statute must be constructed in a manner that expressly accounts for the risk of serious harm.

\section{The Criminalisation of Attempting to Transmit the Virus Within England and Canada}

It has been accepted by the prosecutorial authorities and the Courts ${ }^{172}$ in England that a conviction for an attempt will transpire if the defendant intentionally exposes another to the virus, the risk of transmission being irrelevant. In Canada, the law of attempts has successfully lead to conviction, and Williams was prosecuted for attempting to transmit the virus to an unsuspecting complainant. ${ }^{173}$ The most disconcerting element of the facilitation of the law of attempts is that attempts do not necessitate that the defendant is HIV+ or that there is a significant risk of the virus being transmitted. This provides further justification for requiring a HIV specific law that is sufficiently defined to prohibit specific types of conduct. Proposals for a new legislative framework will now be discussed, and set out, articulating a suggested culpability threshold for transmission/exposure inculpatory conduct, predicated on a review of comparator substantive laws.

\section{Criminalising Exposure and Transmission: A Suggested Statutory Provision}

A legislative framework for criminalising transmission can be justified as a defendant will only be convicted if he transmitted the virus to an unsuspecting complainant. The harm principle advocates this proposal, and the onus will be on the prosecution to adduce sufficient evidence to establish that transmission of the virus to the complainant emanated from the defendant. The discrepancies and deficiencies of utilising the general criminal law for acts of exposure are more evident. In England and Canada, the general criminal law can, or has been, utilised in cases concerning exposure. ${ }^{174}$ This has led to an incremental development of the law in Canada and advocates the need for a specific statutory provision. It would be more appropriate to have a specific piece of legalisation that criminalises HIV exposure to

169. State $v$ Hogg (n 131).

170. Cal. Health \& Safety Code (n 144); Cal. Health \& Safety Code (n 154).

171. For example see: Wash Rev Code (n 102); La. Rev. Stat. Ann. (n 134).

172. Crown Prosecution Service (CPS) (n 24).

173. $R v$ Williams (n 85).

174. Criminal Attempts Act 1981; $R v$ Williams (n 85). 
avoid the haphazard development of the law. An HIV specific law would generally, remove issues of exposure from the law of attempts. This does not infer that all of the bespoke US legislative frameworks correspond to the harm principle as a number of States have enacted laws that are not in accordance to the risk of serious harm. ${ }^{175}$

This lack of lucidity is apparent in all of the countries, but is more noticeable in the States that have been analysed. Some provisions do not take into account the social utility of sexual intimacy and the probability of harm; the primary focus is upon the magnitude of harm. Proponents suggest that any statutory provision that is enacted should utilise terms that equate to the significant risk of harm, as a threshold standardisation. ${ }^{176}$ Any cathartic statutory reform should provide enhanced simplicity and certainty in the law and stipulate directly the type of prohibited activities within the ambit of liability boundaries. Then there is no necessitation to refine the law to provide what is or is not included within the definition. The suggested statutory provision, set out below, delineates two specific offences: one where transmission of the virus will be an offence and the other provision criminalises exposure. A suggested provision that encompasses exposure and transmission could be simply stated to be:

A person will have committed an offence under this statute if he:

1. Intentionally or recklessly transmits HIV to another through unprotected vaginal or anal intercourse or;

2. Intentionally exposes another to HIV by having unprotected vaginal or anal intercourse

The statutory provision corresponds to the harm principle by expressly stating what type of conduct is to be prohibited. Subsection one above ensures that the harm of the virus being transmitted is criminalised and this is an acknowledgment that protective measures are potentially relevant, a further rationale for this stance has been discussed in earlier articles. ${ }^{177}$ This is primarily based upon the current English position, and the question will be whether the jury were convinced that the defendant was reckless in his conduct. This ought to appease proponents of criminalisation of transmission. The core issue vis- à-vis transmission is causation and the ordinary principles of the criminal law would apply in this regard. It does not allow for any further scope, because if a defendant transmits the virus to an unsuspecting complainant through unprotected intercourse he will have committed the offence, unless it can be established that he was responsible rather than reckless with his conduct. ${ }^{178}$ The life debilitating aspects of the virus justify criminalising this type of harm.

The proposed framework that addresses exposure is reliant upon California's repealed statutory provision. ${ }^{179}$ Subsection two above states that intentional behaviour and high risk activities are criminalised. The suggested provision accounts for the magnitude and probability of harm precepts, while considering the social utility of sexual interaction. As unprotected intercourse is criminalised the suggested legal framework encourages condom use.

\section{Conclusion}

The above exposition has demonstrated that the harm principle provides the foundation for criminalising reckless transmission and intentional exposure to the virus. An exploration of the law in England identified that it was appropriate to criminalise transmission, but did not provide a theoretical basis for this approach. The criminalisation of exposure was even further removed from rationalisation, as there is no consideration of the significant risk of serious harm, and thus lacked any justification for this

\footnotetext{
175. For example see: Wash Rev Code (n 102); La Rev Stat Ann (n 134).

176. Kaplan (n 7) 1542.

177. Hughes (n 22).

178. Ibid.

179. Ibid.
} 
sanction. Prima facie the criminalisation of exposure in Canada accords to Feinberg's definition of harm, as the mechanisms to assess the risk that are set out in the leading cases of Cuerrier and Mabior correspond to the definition of the risk of serious harm. Further exploration identified that each test places too much emphasis on the magnitude of harm, and less reliance is placed upon the risk of harm. Thus the discourse of the extant English and Canadian jurisdictions identified that the utilisation of the general criminal law is inadequate, there is too much uncertainty and unfairness.

An examination of the HIV specific legislation within some states from the US identified that a legislative framework necessitates careful consideration. The US statutory provisions that were discussed revealed varying degrees of culpability, as some criminalised exposure without consideration of the risk of serious harm, and denoted that negligible types of exposure could be considered criminal. In contrast other state statutes adhered to the significant risk of serious harm test. A comparison of the English, Canadian and American jurisdictions concluded that it was an Iowa and Californian statute that provided the optimal solution to the criminalisation of exposure to HIV. These provisions were instrumental in facilitating the drafting of a bespoke offence that was robustly tested against the harm principle and the laws of each of the comparative jurisdictions. It is for these reasons that the suggested statutory provision places much emphasis on the types of activity that should be criminalised. ${ }^{180}$

\section{Declaration of Conflicting Interests}

The author(s) declared no potential conflicts of interest with respect to the research, authorship, and/or publication of this article.

\section{Funding}

The author(s) received no financial support for the research, authorship, and/or publication of this article.

180. Hughes, David and Reed, Alan, 'Criminalisation of HIV Transmission: Anglo-North-American Comparative Perspectives and Optimal Reforms to Failure of Proof Defences' in Chris Ashford, Alan Reed, Nicola Wake (eds), Legal Perspectives on State Power: Consent and Control (Scholars Publishing, Cambridge 2016). 